\title{
PENDIDIKAN KARAKTER DALAM KAJIAN FILSAFAT NILAI
}

\author{
Ida Rochmawati
}

Dosen Sekolah Tinggi Ilmu Tarbiyah Raden Santri Gresik

\begin{abstract}
The main goal of becoming human character education in Indonesia. Character education that proclaimed nationally and massif in all levels of education to this point so that learners have a superior character. The application of character education that has gone on for many years such has been his impact can be felt or is only limited to the theory presented in front of the class and become the motto in schools. In the view of philosophy of value, character education is the cultivation of the values that will be embedded in the inside. In Indonesia, it is character education who wish to apply should be tailored to the purpose of education nationally with a system of values that already exist in the community. Among the many values that thrive in the community, in fact Indonesia nation already has the basics of value yanag bermsyarakat life ilandasaan, became a nation and a country.
\end{abstract}

Keywords: character education, the philosophy of values

Di Indonesia, pendidikan karakter kini menjadi tren. Pendidikan Karakter bahkan menjadi keharusan yang wajib ada dalam kurikulum. Dasar filosofisnya entah karena bangsa ini sudah tidak memiliki karakter lagi, atau dunia pendidikan telah melupakan tujuan utamanya pembentukan karakter, atau karena hasil studi banding para pakar pendidikan ke luar Negeri yang melihat bahwa murid-murid di luar negeri memiliki karakter kuat sejak usia dini, entahlah. Namun pendidikan karakter saat ini telah dimplementasikan dalam Kurikulum pendidikan Nasional dan diberlakukan secara massif.

Selama hampir tujuh tahun lebih penerapan pendidikan karakter hasilnya masih banyak siswa dan guru yang membuang sampah sembarangan -sebagai salah satu contoh masyarakat berkarakter adalah masyarakat yang mencintai kebersihan dan disiplin dalam setiap tindakannya termasuk membuang sampah. Di sebuah ruangan seminar di Gresik misalnya yang dihadiri para guru yang jumlahnya tidak sampai 50 orang, setelah seminar berakhir, lantai ruangan penuh 
kotak-kotak snack, gelas air minum kemasan, dan plastik berserakan di seluruh ruangan. Para guru saja yang tugasnya mendidik siswa untuk mengembangkan karakternya, ternyata masih belum berkarakter!

Sangat jauh perbedaannya saat kita melihat kebiasaan-kebiasaan bangsa-bangsa yang karakternya sudah terbangun. Lihat saja seperti di Cina atau Jepang, bagaimana anakanak usia Sekolah Dasar sudah mampu antri demikian rapi ketika jam makan siang, membereskan semua tempat makannya tanpa menyisakan sampah sedikitpun di meja.

Ada pandangan bahwa terdapat pergeseran karakter yang sangat timpang dari era dahulu dengan era sekarang terutama pada kualitas karakter anak didik. Dahulu (era tahun 1980 ke bawah), mayoritas siswa memiliki tingkat sopan santun yang tinggi, ada rasa hormat yang tulus kepada guru, perilaku dan gaya tuturnya halus. Berbeda dengan siswa era sesudahnya di mana hubungan siswa dan guru sudah tidak sesakral dulu bahkan seperti teman. Namun bukan di situ letak persoalannya, karena relasi guru dan siswa dalam pola pembelajaran modern memang lebih egaliter. Yang menjadi persoalan adalah lemahnya karakter yang dimiliki oleh generasi saat ini seperti tingkat kedisiplinan, sifat pekerja keras, rasa percaya diri yang rendah, kurang bertanggung jawab terhadap diri bahkan lingkungannya dsb.

Konon Arus modernisasi dan teknologilah yang menjadi biang keladi lunturnya karakter ini, di mana masa kini teknologi semakin mengalami perkembangan pesat. Bukan hanya di kota-kota besar saja, namun telah meluas di berbagai penjuru desa bahkan daerah-daerah perbatasan di Indonesia. Perkembangan teknologi tersebut mempengaruhi pola pikir dan perilaku masyarakat tidak hanya perubahan secara positif namun juga perubahan negatif. Perubahanperubahan tersebut juga merambah dunia pendidikan dan mempengaruhi pola pikir, pola interaksi dan perilaku warga sekolah, guru maupun siswa.

\section{Pergeseran dan perubahan positif dapat dilihat dengan} peningkatan kualitas pembelajaran, materi, media pembelajaran, networking dsb. Namun di sisi negatif terjadi pergeseran pola perilaku, etika, atau moral siswa. Pergeseran tersebut tampak pada pola tutur kata, pola perilaku, dan kebiasaan. Memang tidak bisa disangkal bahwa karakter yang kuat akan mempengaruhi kehidupan seseorang dalam tahap-tahap perkembangannnya dan menjadi gerbang sukses di masa depannya. Karakter yang kuat akan membentuk mental yang kuat dan sebaliknya. 
Fenomena seperti inilah yang menjadi cikal bakal munculnya pentingnya pendidikan kaarakter sekitar tahun 2010 yang lalu. Keinginan untuk menjadikan kembali proses pendidikan sebagai upaya penyadaran pentingnya norma-norma dan nilai-nilai kehidupan. Inilah kemudian yang dijadikan landasan ide memasukkan pendidikan karakter dalam struktur kurikulum nasional. Internalisasi pendidikan dalam kurikulum yang diejawantahkan dalam setiap program sekolah memang sangat penting. Namun sejauh ini, pendidikan karakter yang telah diintegrasikan dalam kurikulum tersebut mampu mencetak siswasiswa berkarakter atau sebaliknya justru mencetak siswa-siswa yang makin sarat beban, stres, dan justru tidak berkarakter?

Penerapan pendidikan karakter tersebut nampaknya sekedar menyisipkan agenda tanpa mengimbangi dengan konsep yang matang. Pembentukan karakter tidak bisa dibangun hanya satu dua bulan atau satu dua tahun tanpa implementasi total dalam setiap lini, menjadi nafas dari seluruh lingkungan sekolah dan sarat dengan nilai-nilai luhur yang diyakini dan diterapkan secara bersama-sama oleh seluruh warga sekolah. Inilah yang menjadi ketertarikan penulis untuk mencoba menganalisa konsep pendidikan karakter secara Aksiologis, karena dengan meneropongnya secara konseptual terlebih dahulu akan memberikan gambaran secara nyata sebelum melangkah ke tahap implementasi.

Berdasarkan latar belakang masalah di atas, maka permasalahan penelitian ini dapat dirumuskan sebagai berikut :

Bagaimana konsep pendidikan karakter dalam kajian Filsafat Nilai (Aksiologi)?

\section{Metodologi Penelitian}

Untuk memperoleh data yang dibutuhkan dalam penelitian ini menggunakan

\section{Sumber Data}

Penelitian ini termasuk daalam library research, sehingga sumber data yang digunakan adalah datadata kepustakaan baik berupa buku, jurnal, maupun majalah. Dalam hal ini ada dua jenis sumber data yang digunakan; sumber data primer dan sumber data sekunder. Sumber data primer adalah sumber data yang terkait langsung dengan tema. Sementara sumber data sekunder adalah dumber data pendukung tema yang berasal dari berbagai kajian.

\section{Pengumpulan Data}

Pengumpulan data dilakukan dengan menggunakan dokumen-dokumen yang terkait dengan tema penelitian. Data-data tersebut berupa bukubuku, artikel, tulisan lepas atau 
apapun yang terkait dengan penelitian. Data tersebut kemudian dikumpulkan dan dianalisa dengan menggunakan metode analis isi atau kajian isi.

Kajian isi merupakan proses sistematis. Hal ini berarti dalam rangka pembentukan kategori sehingga memasukkan dan mengeluarkan kategori dilakukan atas dasar aturan yang jelas dan relevan.( Lexy J. Moleong: 1998,164)

\section{Analisa Data}

Analisis data yang dapat digunakan oleh penulis adalah analisis isi, untuk memperoleh sebuah pemahaman dan pemaknaan yang cukup akurat. Content analsys merupakan analisis ilmiah tentang isi pesan suatu komunikasi yang secara teknis mengandung upaya: pertama, klasifikasi tanda-tanda yang dipakai dalam komunikasi. Kedua, menggunakan kriteria sebagai dasar klasifikasi dan ketiga, menggunakan teknik analisis tertentu sebagai unsur membuat prediksi.

\section{KAJIAN TEORI}

\section{PENDIDIKAN KARAKTER}

\section{Memaknai Pendidikan karakter}

Secara etimologi karakter
berasal dari bahasa Yunani,
charassein, yang berarti mengukir.
Sifat utama ukiran adalah melekat

kuat di atas benda yang diukir. (Abdullah Munir: 2010). Tidak mudah luntur oleh waktu dan aus oleh gesekan. Menghilangkan ukiran sama dengan menghilangkan benda tersebut karena ukiran telah menyatu dengan bendanya. Ini berbda dengan gambar atau tulisan tinta yang hanya disapukan di atas permukaan benda yang mudah hilang dan tidak meninggalkan bekas jika dihapus.

M. Furqon Hidayatullah mengutip pendapat Rutland (2009:1) yang mengemukakan bahwa karakter berasal dari akar kata bahasa latin yang berarti "dipahat". Secara harfiah, karakter artinya adalah kualitas mental atau moral, kekuatan moral, nama atau reputasinya. Dalam kamus psikologi, dinyatakan bahwa karakter adalah kepribadian ditinjau dari titik tolak etis atau moral, misalnya kejujuran seseorang ; biasanya mempunyai kaitan dengan sifat-sifat yang relative tetap.( Dali Gulo: 1982, 29)

Jika seseorang memiliki sebuah sifat buruk, meski telah diberi nasehat ratusan kali, masukan dari manapun, sifatnya tidak berubah, mungkin berubah sesaat saat diberi nasehat namun akan muncul lagi dalam waktu yang tidak terlalu lama. Sifat tersebut sudah melekat dan sulit diubah, itulah karakter. (Abdullah Munir: 2010)

Kebiasaan yang dilakukan secara terus menerus dan berulang- 
ulang yang didahului oleh kesadaran dan pemahaman akan menjadi karakter seseorang. Gen hanya menjadi salah satu faktor penentu saja. Namun orang tualah yang akan memiliki peluang besar dalam menentukan karakter anak. Orang tua di sini bisa dimaknai orang tua kandung atau orang tua yang lebih luas. Seperti orang-orang dewasa yang berada di sekeliling anak dan memberikan peran yang berarti pada anak.

\section{Tujuan Umum Pendidikan Karakter}

Jika pendidikan karakter menjadi pilihan untuk diterapkan, konsekuensinya adalah meninjau ulang kurikulum yang berlaku saat ini yang sangat sarat beban bagi siswa. Hal ini untuk memberikan ruang yang cukup bagi masuknya pendidikan karakter. ( Jamal Ma'mur Asmani: 2011, 32). Dengan padatnya beban materi dan jam pelajaran saat ini akan sulit bagi pendidikan karakter diberlakukan. Untuk membangun kultur sekolah akan membutuhkan waktu minimal tiga bulan pertama di tiap tahun ajaran. Jika tiga bulan ini guru sudah dibebani dengan berbagai materi pelajaran peluang untuk membangun karakter akan hilang.

\begin{tabular}{lr}
\multicolumn{2}{c}{ Memberikan pendidikan } \\
karakter bertujuan & untuk \\
menumbuhkan karakter & positif, \\
karena karakter sebenarnya memiliki
\end{tabular}

dua sisi, positif dan negatif. Dengan memberikan pendidikan karakter dua sisi karakter hanya akan tergali sisi positifnya saja, sementara sisi negatifnya akan tumpul bahkan tidak berkembang. Misalnya rasa yakin akan menumbuhkan keberanian bukan kesombongan, rasa takut akan menumbuhkan kehati-hatian bukan pengecut, rasa malu akan menumbuhkan kesopanan bukan keminderan.Untuk mencapai tujuan terbentuknya karakter positif tersebut, pendidikan karakter tidak terlepas dari nilai-nilai tentang benar dan salah. (Abdullah Munir: 2010)

\section{Tujuan, Fungsi dan Media Pendidikan Karakter}

Dalam buku pedoman
pelaksanaan pendidikan karakter
oleh Badan Penelitian dan
Pengembangan KEMDIKNAS 2011
menyatakan bahwa tujuan, fungsi
dan media pendidikan karakter
adalah sebagai
berikut: (Kemendiknas: 2011, 8)
a. Tujuan pendidikan karakter adalah untuk mengembangkan karakter bangsa agar mampu mewujudkan nilai-nilai luhur pancasila.
b. Fungsi pendidikan karakter adalah :
1) Untuk mengembangkan potensi dasar, agar berhati baik, berpikiran baik dan berprilaku baik. 
2) Memperkuat dan membangun perilaku bangsa yang multikultur (memperkuat perilaku yang sudah baik)

3) Meningkatkan peradaban bangsa yang kompetitif dalam pergaulan dunia (penyaring budaya yang kurang sesuai dengan nilai-nilai luhur Pancasila)

c. Media pendidikan karakter antara lain :

1) Keluarga

2) Satuan pendidikan

3) Masyarakat sipil

4) Pemerintah

5) Dunia Usaha, dan

6) Media Massa

\section{Dasar Hukum Pendidikan Karakter}

Dasar hukum pembinaan pendidikan karakter adalah sebagai berikut :

a. Undang-Undang Dasar 1945

b. Undang-Undang Nomor 20 Tahun 2003 tentang Sistem Pendidikan Nasional

c. Peraturan Pemerintah Nomor 19 Tahun 2005 tentang Standar Nasional Pendidikan d. Permendiknas Nomor 39 Tahun 2008 tentang Pembinaan Kesiswaan

e. Permendiknas Nomor 22 Tahun 2006 tentang Standar Isi

f. Permendiknas Nomor 23 Tahun 2006 tentang Standar Kompetensi Lulusan

g. Rencana Pemerintah Jangka Menengah Nasional 2010 - 2014

h. Renstra Kemendiknas Tahun 2010 - 2014

i. Renstra Direktorat Pembinaan SMP Tahun 2010 - 2014. (Jamal Ma'mur Asmani 2011, 32)

\section{Tahap-tahap Pendidikan Karakter}

Pendidikan karakter membutuhkan proses atau tahapan secara sitematis dan gradual, sesuai dengan fase pertumbuhan dan perkembangan anak didik. Menurut Ary Ginanjar Agustian, Pembangunan Karakter tidaklah cukup hanya dimulai dan diakhiri dengan penetapan misi. Akan tetapi, hal ini perlu dilanjutkan dengan proses yang dilakukan secara terus menerus sepanjang hidup.

Sementara itu klasifikasi pendidikan karakter dalam beberapa tahap, berdasarkan Hadits Rasulullah SAW adalah sebagai berikut :

a. Tahap penanaman adab (umur 5-6 tahun) 
b. Tahap penanaman tanggung jawab (umur 7-8 tahun)

c. Tahap penanaman kepedulian (umur 9-10 tahun)

d. Tahap penanaman kemandirian (umur 11-12 tahun)

e. Tahap penanaman pentingnya bermasyarakat (umur 13 tahun ke atas)

Lima tahap pendidikan karakter ini menjadi pondasi kokoh dalam menggali, melahirkan, mengasah, serta mengembangkan bakat dan kemampuan unik siswa. Hal ini menjadi penting untuk menghadapi tantangan globalisasi yang dahsyat dan spektakuler sekarang ini.

\section{Pilar Pendidikan Karakter}

\section{Menurut Suparlan, para penggiat pendidikan karakter mencoba melukiskan pilar-pilar penting dalam pendidikan karakter, jelaslah bahwa pendidikan karakter meliputi 9 (sembilan) pilar yang saling kait mengait. Kesembilan pilar tersebut adalah :}
a. Responsibility (Tanggung Jawab)
b. Respect (Rasa Hormat)
c. Fairness (Keadilan)
d. Courage (Keberanian)
e. Honesty (Kejujuran)

\author{
f. Citizenship \\ (Kewarganegaraan) \\ g. Self Discipline (Disiplin \\ Diri) \\ h. Caring (Peduli)
}

\section{Peran Guru dalam Pendidikan Karakter}

Guru merupakan sosok yang menjadi idola bagi anak didik. Keberadaannya sebagai jantung pendidikan tidak bisa dipungkiri. Baik atau buruknya pendidikan sangat tergantung pada sosok yang satu ini. Segala upaya sudah harus dilaksanakan untuk membekali guru dalam menjalankan fungsinya sebagai actor penggerak sejarah peradaban manusia dengan melahirkan kader-kader masa depan bangsa yang berkualitas paripurna, baik sisi akademik, afektif dan psikomotorik. Menurut E. Mulyasa, fungsi guru itu bersifat multifungsi. Ia tidak hanya sebagai pendidik, tapi juga sebagai pengajar, pembimbing, pelatih, penasihat, pembaru, model dan teladan, pribadi, peneliti, pendorong kreatifitas, pembangkit pandangan, pekerja rutin, pemindah kemah, pembawa cerita, actor, emancipator, evaluator, pengawet dan kulminator. (H.E.Mulyasa: 2005, 37-64)

\section{Implementasi Pendidikan Karakter}

Pendidikan karakter adalah suatu sistem penanaman nilai-nilai karakter kepada sekolah yang meliputi komponen pengetahuan, kesadaran atau kemauan dan tindakan untuk melaksanakan nilai- 
nilai tersebut, baik terhadap Tuhan Yang Maha Esa, diri sendiri, sesama, lingkungan, maupun kebangsaan sehingga menjadi insan yang kamil. (elementary-education-

school.blogspot.com: 18 Mei 2012)

Dalam pendidikan karakter di sekolah semua komponen harus dilibatkan, termasuk komponenkomponen pendidikan itu sendiri yaitu, isi kurikulum, proses pembelajaran dan nilai, kualitas hubungan, penanganan atau pengelolaan mata pelajaran, pengelolaan sekolah, pelaksanaan aktivitas atau kegiatan kokurikuler, pemberdayaan sarana prasarana, pembiayaan, ethos kerja seluruh warga, dan lingkungan sekolah.

TINJAUAN

FILSAFAT (AKSIOLOGI)

\section{Makna Aksiologi}

Berasal dari bahasa Yunani "axios" yang berarti layak; pantas; nilai dan Logos yang berarti ilmu. Beberapa pengertian menurut istilah antara lain:

a. Aksiologi merupakan analisis tentang nilai-nilai yang berarti membatasi arti, ciri-ciri, asal, tipe, kriteria atau status epistemologi ari nilai tersebut.

b. Aksiologi merupakan studi yang menyangkut teori umum tentang nilai dan segala sesuatu yang bernilai.
c. Aksiologi adalah studi filosofis tentang hakikat nilai-nilai.

Nilai merupakan tema baru dalam kajian filsafat, muncul pertama kali pada abad ke-19. Aksiologi adalah ilmu pengetahuan yang menyelidiki hakikat nilai yang pada umumnya ditinjau dari sudut pandang filsafat. Di dunia ini ada banyak cabang pengetahuan yang bersangkutan dengan mpersoalan nilai yang khusus seperti epistemologis, etika dan estetika. Epistemologi berhubungan dengan kebenaran, etika berkaitan dengan masalah kebaikan dan estetika bersangkutan dengan masalah keindahan. (Louis O.Kattsof 1992, 327)

Nilai itu ideal dan bersifat ide. Sehingga ia bersifat abstrak dan tidak dapat disentuh oleh panca indra. I.A.Richard membedakan antara makna faktual dan makna emotif. Secara historis emotivisme berasal dari logika positivisme: bahwa nilai adalah sesuatu yang tidak dapat dijelaskan dan bersifat emotif, meski memiliki makna secara faktual. Nilai sama sekali tidak dapat digambarkan sebagai keadaan suatu subyek, obyek, ataupun sebagai hubungan. (Uyoh Sadullah: 2007, 36)

Teori umum tentang nilai muncul dari perdebatan antara Alexius meinog dengan Christian von Ehrenfels pada tahun 1890-an berkaitan dengan sumber nilai. Meinog memandang bahwa sumber nilai adalah perasaan (feeling), atau perkiraan atau kemungkinan adanya kesenangan terhadap suatu obyek. 
Ehrenfels (termasuk Spinoza) memandang bahwa sumber nilai adalah hasrat/keinginan (desire). Suatu obyek menyatu dengan nilai melalui keinginan aktual atau yang memungkinkan, artinya suatu obyek memiliki nilai karena ia menarik. Menurut kedua pendapat tersebut, nilai adalah milik obyek itu sendirisendiri. (Ahmad Faruq: 2009, 104) Pertanyaannya kemudian, apakah nilai yang dimiliki obyek itu memang benar-benar dari obyek tersebut ataukah karena persepsi kita terhadap obyek tersebut?

\section{Nilai dan kebaikan}

Baik dan benar adalah dua hal yang tidak identik, meski keduanya bersifat positif. Yang baik mungkin juga tidak benar yang benar itu juga bisa dianggap baik atau buruk. Tapi ketika yang baik itu berkaitan dengan yang benar (atau sebaliknya) maka itulah yang ideal. (Sidi Gazalba: 2001, 7)

Filsafat nilai pada masa modern (Max Scheler) yang bermula dari Lotze membuat perbedaan tajam antara nilai dan kebaikan. Karena nilai-nilai dalam arti ini dipikirkan sebagai ide-ide dari dunia lain yang dapat diperkenalkan kepada dunia nyata dengan peralatan manusia, pandangan ini dinamakan teori 'idealisme nilai'. Lawan idealisme nilai adalah metafisika nilai yang mengatais pemisahan nilai dari yang ada (al-mawjud).

\section{Pendekatan-pendekatan dalam aksiologi :}

- Nilai sepenuhnya bersifat subyektif, dinilai dari sudut pandang ini nilai-

nilai merupakan reaksi

yang diberikan oleh manusia sebagai pelaku dan keberadaanya tergantung pada pengalamanpengalamannya.

- Nilai-nilai merupakan kenyataan yang ditinjau dari segi ontologi namun tidak terdapat dalam ruang dan waktu. Nilai-nilai tersebut merupakan esensi logis dan diketahui melalui akal. (obyektivisme logis)

- Nilai-nilai merupakan unsur-unsur obyektif yang menyusun kenyataan (obyektivisme metafisik). (Louis O.Kattsof 1992, 331)

\section{Persoalan aksiologis dalam kehidupan sehari-hari}

Bila dua orang tidak sependapat mengenai suatu hal misalnya makanan atua minuman yang menynangkan atau tidak menyenangkan, dan mereka gagal untuk saling meyakinkaan, diskusi pada umumnya berakhir dngan pernyataan darisalah satu pihak bahwa ia menyenangi atau tidak menyenangi hal itu, dan tidak seorangpun yang dapat meyakinkan laaawan bicaranya. Seperti halnya peribahasa latin "selera tidak dapat diperdebatkan" (de gustibus non disputandum). Orang yang mendukung de gustibus non disputandum ingin menunjukkan satu ciri khs nilai, yaitu sifat yang 
mendalam dan langsung dari penilaian.

$\begin{array}{crr}\begin{array}{c}\text { Konflik } \\ \text { menggelitik }\end{array} \text { bagi } & \begin{array}{r}\text { sangat } \\ \text { aksiologi }\end{array}\end{array}$
kontemporer. Sebenarnya hal itu lahir dari aksiologi itu sendiri dan sejarah tentang nilai, dengan memandang persoalan ini sebagai sumber dan dengan mensketsakan berbagai penyelesaian yang telah dikemukakan dalama rangka menyelesaikannya, meski maknanya bisa berbeda. Persoalan tersebut telah muncul pada zaman Plato,; shakespeare yang menempatkannya dalam Troilus and cresida (II,2) dan spinoza memilih salah satu alternatif di dalam etika-nya (III, prop, IX). (Risieri Frondizi: 2001,16-19)

\section{PENDIDIKAN KARAKTER DALAM FILSAFAT NILAI}

\section{Pendidikan sebagai upaya Penanaman Sistem Nilai}

Dalam dunia yang serba global saat ini, nilai juga memegang peranan penting dna telah mengalami perkembangan yang global pula. Saat ini hampir tidak ada batas ruang karena dunia sudah terkoneksikan dengan mudah, jarak sudah tidak berarti dan hubungan antar personal, antar masyarakat bahkan antar negara hampir bisa dilakukan kapanpun dan di manapun. Tentu saja pola hubungan ini juga turut mengubah cara pandang masyarakat terhadap nilai yang mereka yakini.

Setiap negara, setap kelompok bahkan setiap individu memiliki nilai yang telah diyakininya, dan menginginkan orang lain, kelompok lain atau negara lain menganut atau mengikuti nilai-nilai tersebut dengan berbagai cara. Seperti inilah proses globalisasi berlangsung, di mana nilai-nilai juga turut mengglobal. (Ahmad Tafsir: 2008, 49)

\section{Pendidikan Karakter dan Etika}

Pendidikan dan etika memiliki keterkaitan yang sangat erat. Ketika etika berbicara tentang yang baik dan buruk. Masalah moral tidak bisa dilepaskan dengan tekad manusia untuk menemukan kebenaran, sebab untuk menemukan kebenaran dan terlebih untuk mempertahankan kebenaran, diperlukan keberanian moral. (Jujun S. Suriasumantri: 1998,235)

\section{Sulit} memyangkan perkembangan iptek tanpa adanya kendali dari nilai-nilai etika moral dan agama. Untuk itulah kemudian ada konsep pendekatan konseptual yang dapat dipergunakan sebagai jalan pemecahannya, yaitu dengan menggunakan pendekatan etikmoral, di mana setiap persoalan pendidikan berangkat dari perspektif yang mengikutsertakan kepentingan masing-masing pihak baik siswa, guru, pemerintah maupun masyarakat luas. Ini berarti pendidikan akan lenih diorientasikan kepada upaya menciptakan kepribadian yang berkarakter. Tidak hanya pada siswa melainkan seluruh komponen yang terlibat dalam penyelenggaraan pendidikan. Tidak hanya siswa yang dituntut berkarakter namun semua komponen yang terlibat di dalamnya juga harus berkarakter positif dan kuat. 


\section{Sistem nilai ideal yang diperlukan dalam pembentukan karakter.}

Dalam kerangka idealisme kenyataan yang ada dalam kehidupan bukanlah suatu kebenaran yang bersifat hakiki, melainkan gambaran dari ide-ide yang ada di dalam jiwa atau spirit manusia. Pementukan karakter memerlukan seperangkat nilai yang akan diberikan kepada anak didik dan menjadi budaya di lingkungan pendidikaan formal maupun non formal.

\section{Subyektivisme} dan relativisme nilai melahirkan aliranaliran dan teori dalam pendidikan yang berimplikasi pada pola perlakuan terhadap anak didik. John Locke misalnya yang berpendapat bahwa pengalaman yang akan membentuk kepribadian anak didik. Atau aliran behaviorisme yang dipepolopi oleh Pavlov, yang berpendapat bahwa manusia harus dikondisikan sejak lahir dan diberi rangsangan agar berkembang sesuai dengan yang diharapkan. (Muzayyin Arifin: cet ke 5)

Kepercayaan, sikap, nilainilai manusia merupakan refleksi dari lingkungan sekitar yang telah dikondisikan.dengan melalui indoktrinasi, propaganda, atau counter propaganda, kepercayaan, sikap-sikap dan niali-nilai yang dipegang nanusia dapat dibentuk bukan karena perkembangan moralitas yang inheren dari kapasitasnya sebagai manusia. Nilai moral dan etika dalam pandangan teori ini bersifat relatif, tidak mutlak dan berubah-ubah tergantung waktu dan tempat, sehingga masalah baik dan buruk tidak lagi dipersoalkan. Penalaarnlah yang menjadi standar bagi yang 'baik' dan 'buruk'

Sementara naturalisme menolak hal-hal yang bersifat spritual dan moral sebab kenyataan yang hakiki adalah alam semesta yang bersifat fisik. Sementara Pragmatisme lebih mementingkan paham antroposentris (berpusat pada manusia), kepada batin manusia, kepada kemampuan kreativitas dan pertumbuhan manusia, kepada halhal yang bersifat praktis, kemampuan kecerdasan, perbuatan dalam masyarakat dan kepada diri manusia sendiri (individualitas).

\section{KESIMPULAN}

Kesimpulan yang dapat dirumuskan dalam apenelitian ini adalah bahwaKarakter merupakan satu bentukan perilaku yang bersifat permanen. Di mana bentukan tersebut melibatkan standar nilainilai yang dibangun oleh masyarakat yang bersifat relatif subyektif ataupun nilai ideal yang bersifat absolut.

Dalam pandangan filasafat nilai pendidikan karakter dipandang sebagai sebuah proses pembentukan Pendidikan karakter yang disusun sebaiknya harus didahului oleh kajian komprehensif tentang sistem nilai dan norma yang menjadi pilihan agar implementasi yang akan dilakukan akan lebih terarah dan terinternalisasi secara mendalam sehingga mewujud dalam pola kepribadian serta bangunan karakter yanag kuat. 


\section{DAFTAR RUJUKAN}

Arifin, Muzayyin, Filsafat Pendidikan Islam, jakarta, Bumi Aksara, cet ke 5
Asmani, Jamal Ma'mur, Buku Panduan Internalisasi
Pendidikan Karakter di Sekolah, Jogjakarta, DIVA Press, 2011

Faruq, Ahmad, Filsafat Umum, Ponorogo, STAIN PO Press, 2009

Frondisi, Riseri, Filsafat Nilai, Yogyakarta, Pustaka Pelajar, 2001

Gazalba, Sidi, Sistematika Filsafat; Buku keempat, Pengantar kepada Teoi Nilai, Bulan Bintang, Jakarta, 2001

Kattsof, Louis O., Pengantar Filsafat, Terj. Soejono Soemargono, Tiara Wacana, Yogyakarta, cet ke lima, 1992

Kemendiknas, Pedoman Pelaksanaan Pendidikan Karakter Berdasarkan Pengalaman di Satuan Pendidikan Rintisan, Gresik, Pusat Kurikulum dan Perbukuan 2011

Moleong, Lexy J. , Metodologi Penelitian Kualitatif, Bandung, Remaja Rosdakarya, cet IX , 1998

Mulyasa, H.E. Menjadi Guru Profesional, Bandung, Remaja Rosda Karya, 2005
Munir, Abdullah, Pendidikan Karakter Membangun karakter Anak sejak dari Rumah, Pedagogia, Yogyakarta, 2010

Muttaqin, Zainal, Sistem Sosial Budaya Indonesia, Banten, Universitas Serang Raya 2010

Sadullah, Uyoh, Pengantar Filsafat Pendidikan, Penerbit Alfabeta, Bandung, 2007

Suriasumantri, Jujun S., Filsafat Ilmu Sebuah Pengantar Populer, 1998, Jakarta, Pustaka Sinar Harapan

Tafsir, Ahmad, Filsafat Pendidikan Islami, Bandung, Rremaja Rosdakarya, cet ke 32008 